\title{
Gain Enhancement of Microstrip Patch Antenna and Array Antenna Using Different Metamaterial Structures for Telemedicine Applications
}

\author{
Parisa Shirvani ${ }^{1, *}$, Hamidreza Shirzadfar ${ }^{2, \dagger}$ \\ 1 Sepahan Institute of Higher Education, Sepahan-shahr, Isfahan, Iran \\ 2 Department of Electrical and Biomedical Engineering, Faculty of Engineering and Technology, \\ Shahid Ashrafi Isfahani University, Isfahan, Iran
}

(Received 23 March 2020; revised manuscript received 15 October 2020; published online 25 October 2020)

\begin{abstract}
Telemedicine is a form of remote medical practice using information and communication technologies which facilitates distance mediation between the patient and the medical staff. In rural or remote areas where many of the specialized medical services required by the community do not reach, telemedicine can be a viable and reliable alternative to facilitate access to these services as the use of telemedicine technology leads to higher levels of health care and treatment. As in telemedicine systems antennas have an important role, we focus on the optimal design of used antennas to achieve better results. The role of an antenna is to convert the electrical energy of a signal into electromagnetic energy, or conversely to convert electromagnetic energy into electrical energy. A transmitting antenna is a device that transmits energy between an emitter and the free space where this energy will propagate. The rapid development of wireless communication systems has led to numerous improvements in telecommunication antennas and systems to meet the needs of telemedicine applications. The microstrip patch antenna is a planar antenna that has received a lot of attention due to its flat geometry. These types of antennas are very popular among designers and are used in many applications. This paper presents an improved patch antenna and array antenna with microstrip feed line using three kinds of metamaterial (MTM) structures that can be very useful in telemedicine systems. A metamaterial is an artificial composite material with unnatural electromagnetic properties. Different structures are considered and analyzed to reach a good performance antenna. Proposed structures increase the gain of antennas which are used in telemedicine systems. The structures of the mushroom-like electromagnetic band gap (EBG), the one layer and two-layer woodpile EBG in straight and curved forms have been discussed and analyzed. The operating frequency is $2.45 \mathrm{GHz}$ for telemedicine applications. The simulation process has been done through High Frequency Structure Simulator (HFSS) software and the results are compared.
\end{abstract}

Keywords: Telemedicine, HFSS, Patch antenna, Metamaterial, EBG, Woodpile, Mushroom-like, Array antenna.

DOI: 10.21272/jnep.12(5).05034

PACS numbers: 84.40.Ba, 84.40.Ua

\section{INTRODUCTION}

Telemedicine is a form of remote medical practice using information and communication technologies. It is also an important vector for improving access to health care, particularly in underprivileged areas [1-3]. Telemedicine is even presented as a necessity of law and which makes law, in the first sense. The use of telemedicine should facilitate access to care, especially in densely populated areas by allowing patients to obtain faster charging and tracking that may in some situations prevent some hospitalizations and re-hospitalizations and to reduce the need for emergencies [4].

Medical tele-assistance by telephone began in the 1920 s to provide care during transatlantic cruises [5]. Then, in 1950, transferring medical images (radiology) began with the work of radiologist Jacob GershonCohen. Then, tele-psychiatry took off in 1959 with the first remote consultation by video. This discipline subsequently developed with the care of Vietnam War veterans throughout the country. Later, in 1964, the video distance training of American healthcare professionals began. Canada was also a pioneer country and, in Europe, Norway and France were the pioneer countries in telemedicine. In France, the first initiatives were devel- oped after the war in the Midi-Pyrénées region under the leadership of Dr. Louis Lareng.

The discipline was institutionalized in 1973 with the first International Congress of Telemedicine in the USA [6]. During this congress, it was noted that information and communication technologies were not sufficiently developed for the moment to allow quality remote support. Telemedicine therefore benefited greatly from the technological advances of the 1980s and 1990s [7].

The rapid development of wireless communication systems has led to numerous improvements in telecommunication antennas and systems to meet the needs of telemedicine applications [8]. An antenna is one of those devices which play an important role in improving the performance of telemedicine systems. An antenna is a device used to radiate the electromagnetic field into space or alternatively to capture. There are several types of antennas such as satellite dishes, patch antennas, Yagi antennas, dipole antennas, etc. [9].

Microstrip patch antennas have become very popular over the past few decades due to lightweight, low profile, conformable to planar and non-planar surfaces and easy to fabricate. An individual microstrip patch antenna is made up of a piece of sheet metal of various shapes (a patch antenna) on the surface of a dielectric

\footnotetext{
*p.shirvani@sepahan.ac.ir

† hsh@ashrafi.ac.ir, h.shirzadfar@gmail.com
} 
with a ground plane on the other side.

The frequency of $2.45 \mathrm{GHz}$ that is belonging to UHF band is proposed as a frequency in telemedicine applications due to being free of charge, existing no frequency interference, using for the WiFi telecommunication [10].

In this paper, the metamaterial structures have been added to the microstrip rectangular patch, patch tree-antenna and array antenna due to better results.

\section{PATCH ANTENNA}

The role of an antenna is to convert the electrical energy of a signal into electromagnetic energy, or conversely to convert electromagnetic energy into electrical energy. A transmitting antenna is a device that transmits energy between an emitter and the free space where this energy will propagate. Microstrip patch antennas have received a lot of attention in recent decades thanks to special features such as their flexibility, low weight, low fabrication cost etc. [11]. However, low gain is a disadvantage of microstrip antennas. Here, metamaterial structures are used to overcome the drawback of microstrip patch antenna.

Three parameters are required to design a microstrip rectangular patch antenna (MRPA) [12]: dielectric constant for substrate $\left(2.2 \leq \varepsilon_{r} \leq 12\right)$, resonant frequency $\left(f_{r}\right)$ and height of the substrate $(h)$. Using these parameters, the dimensions of the patch are calculated.

The design equation for the width of the patch [12]:

$$
w=\frac{c}{2 f_{0} \sqrt{\frac{\varepsilon_{r}+1}{2}}} .
$$

The effective dielectric constant is given by:

$$
\varepsilon_{\text {eff }}=\frac{\varepsilon_{r}+1}{2}+\frac{\varepsilon_{r}-1}{2}\left[1+12 \frac{h}{w}\right]^{-\frac{1}{2}},
$$

where $\varepsilon_{r}$ is the relative permittivity of the substrate, $h$ is the height of the substrate, $w$ is the width of the patch.

The effective length of the patch is calculated by:

$$
l_{\text {eff }}=\frac{c}{2 f_{0} \sqrt{\varepsilon_{e f f}}},
$$

where $f_{0}$ is the operating frequency of the patch.

Equation for the difference in the length

$$
\Delta l=0.412 h \frac{\left(\varepsilon_{e f f}+0.3\right)\left(\frac{\omega}{h}+0.264\right)}{\left(\varepsilon_{e f f}-0.258\right)\left(\frac{\omega}{h}+0.813\right)} .
$$

The actual length of the patch is given as

$$
l=l_{\text {eff }}-2 \Delta l .
$$

Fig. 1 presents the structure of a typical microstrip patch antenna and Table 1 demonstrates its dimensions.

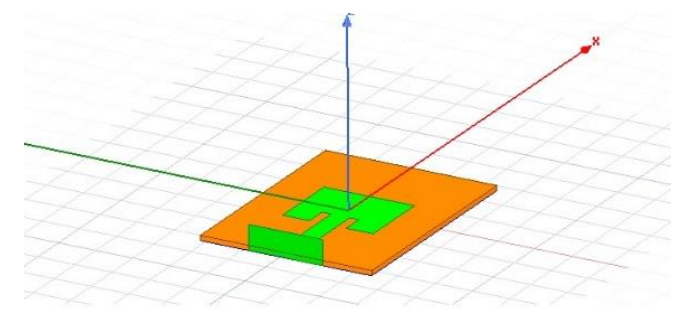

Fig. 1 - Microstrip patch antenna

Table 1 - Dimensions of the patch antenna

\begin{tabular}{|l|l|l|}
\hline № & Parameters & Dimensions \\
\hline 1 & $a$ patch dimension of $X$ & $39.72 \mathrm{~mm}$ \\
\hline 2 & $b$ patch dimension of $Y$ & $48.63 \mathrm{~mm}$ \\
\hline 3 & $X$ substrate dimension & $120.47 \mathrm{~mm}$ \\
\hline 4 & $Y$ substrate dimension & $92 \mathrm{~mm}$ \\
\hline 5 & $X$ feed dimension & $37.508 \mathrm{~mm}$ \\
\hline 6 & $Y$ feed dimension & $9.868 \mathrm{~mm}$ \\
\hline
\end{tabular}

\section{METAMATERIAL}

A metamaterial is an artificial composite material with unnatural electromagnetic properties. It consists of man-made composite materials which have unique or outof-scope response functions and dispersion relationships. Metamaterials were invented in the late 1960s [13].

As you know, periodic structures are found in abundance in nature, now imagine these alternative structures and electromagnetic waves acting on each other. In this case, very amazing results will be achieved. Patch antennas along with metamaterial structures can be used in order to improve the radiation parameters [14]. The Electromagnetic Band Gap (EBG) structures are one kind of metamaterials which are capable of suppressing the surface waves within the substrate.

In general, EBG structures which show attractive and special features are divided into three categories:

1. three-dimensional volumetric structures;

2. two-dimensional flat plates;

3. one-dimensional transmission line.

A mushroom-like EBG structure is one kind of dimensional metamaterial structures which are structures with the presence of a via. The main advantage of two-dimensional structures is their small size, lightweight and low cost of construction. The unique properties of EBG structures such as a reduction of surface waves and an increase in antenna gain have led to their widespread use in the design of antennas [15].

A mushroom-type EBG is a combination of square patches, each having a via which connects the patch to the ground plane. This structure behaves as a parallel resonant $L C$ circuit and gives a better performance.

The parameters of a mushroom-like EBG structure are the width of the EBG patch $w \_e b g$, the gap between adjacent patches $g$ and the radius of the via $r$ [16]:

$$
\begin{aligned}
& w_{-} e b g=0.10 \lambda_{12} \\
& g=0.02 \lambda_{12} \\
& r=0.005 \lambda_{12}
\end{aligned}
$$


$\lambda_{1}$ is the free space wavelength corresponding to the operating frequency of the patch and $\lambda_{2}$ is the wavelength of the wave considering the dielectric constants of both the substrates. Also, the values of $L$ and $C$ belonging to the $L C$ circuit are expressed as:

$$
\begin{aligned}
& L=\mu_{0} h\left[\ln \frac{4 h}{d}+0.5 \frac{d}{h}-0.75\right] \\
& C=\frac{\omega \varepsilon_{0}\left(\varepsilon_{r 1}-\varepsilon_{r 2}\right)}{\pi} \cdot \cosh ^{-1}\left[\frac{2 \omega+g}{g}\right]
\end{aligned}
$$

The schematic of a microstrip patch antenna with a mushroom-like EBG is shown in Fig. 2 and also Table 2 consists of dimensions of this antenna.

A woodpile EBG is another metamaterial structure which is shown in Fig. 3. This type of structure is a three-dimensional structure which consists of several layers that are placed vertically on top of each other [17]. Each of these layers is made up of dielectric rods that are placed parallel to each other. Relative permittivity of dielectric rods is 8.4 and dielectric loss tangent is assumed to be 0.002 . The dimensions of rods are $2 \mathrm{~mm} \times b \times 2 \mathrm{~mm}$ (along $Y$ ) or $a \times 2 \mathrm{~mm} \times 2 \mathrm{~mm}$ (along $X$ ) which is presented in Table 3. Also the difference between woodpile rods and the patch is equal to a factor of half the wavelength [18].

It is shown in Fig. 4 that the gain of a usual patch, a patch with a mushroom-like EBG and a patch with a woodpile EBG is consequently $7.5,8.2$ and $9.5 \mathrm{~dB}$. The following diagram of gain plot at phi $=90$ is shown in Fig. 5.

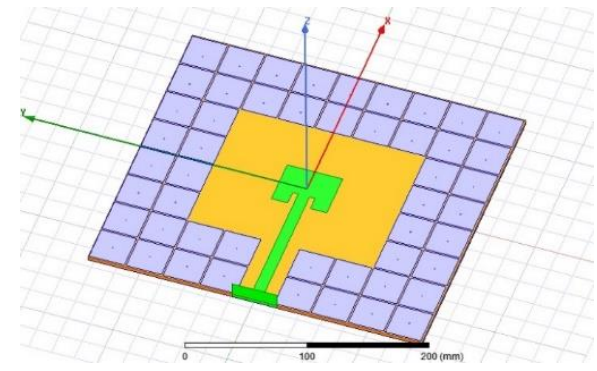

Fig. 2 - Microstrip patch antenna with a mushroom-like EBG

Table 2 - Dimensions of the mushroom-like EBG structure

\begin{tabular}{|l|l|}
\hline \multicolumn{1}{|c|}{ Parameters } & Dimensions \\
\hline$w \_e b g$ & $31 \mathrm{~mm}$ \\
\hline$g$ & $1.5 \mathrm{~mm}$ \\
\hline$r$ (radius of via) & $0.5 \mathrm{~mm}$ \\
\hline$n$ (number of EBGs) & 50 \\
\hline
\end{tabular}

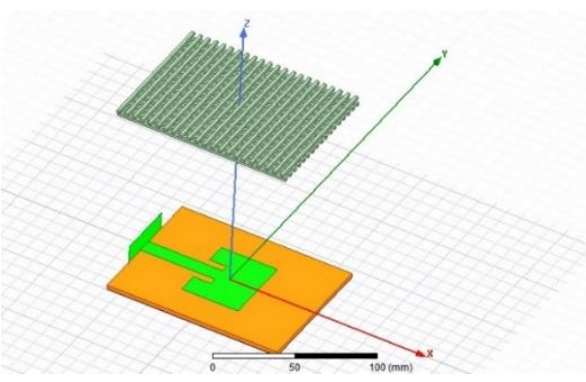

Fig. 3 - Microstrip patch antenna with a woodpile EBG
Table 3 - Dimensions of the woodpile EBG structure

\begin{tabular}{|l|l|}
\hline \multicolumn{1}{|c|}{ Parameters } & Dimensions \\
\hline Woodpile $Y$ dimension of $X$ & $2 \mathrm{~mm}$ \\
\hline Woodpile $Y$ dimension of $Y$ & $b$ \\
\hline Woodpile $Y$ dimension of $Z$ & $2 \mathrm{~mm}$ \\
\hline Woodpile $X$ dimension of $X$ & $a$ \\
\hline Woodpile $X$ dimension of $Y$ & $2 \mathrm{~mm}$ \\
\hline Woodpile $X$ dimension of $Z$ & $2 \mathrm{~mm}$ \\
\hline Height of patch & $150.45 \mathrm{~mm}$ \\
\hline
\end{tabular}

a



$\mathrm{b}$

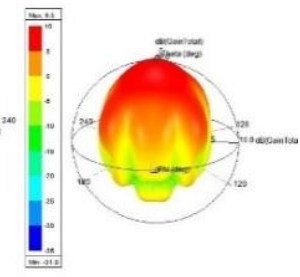

$\mathrm{C}$
Fig. 4 - The 3D polar plot of (a) microstrip patch antenna; (b) mushroom-like EBG structure; (c) woodpile EBG structure

Then the expressed metamaterial structures are applied to a microstrip tree-patch antenna (Fig. 6) (presented in the previous article [19]) and the results are as follows (Fig. 7). The results show that the gain of a tree-patch antenna with EBG structure has increased.



Fig. 5 - Gain plot of a microstrip patch antenna at phi $=90$, a mushroom-like EBG and a woodpile EBG at phi $=90$

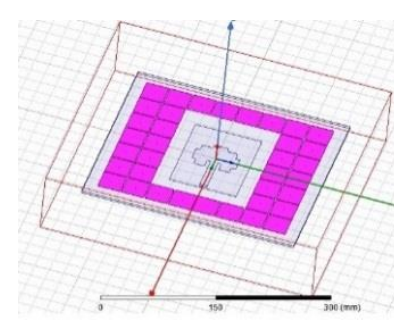

a



$\mathrm{b}$
Fig. 6 - The schematics of microstrip antennas applied by metamaterial. Microstrip tree-patch antenna with a mushroom-like EBG (a), microstrip tree-patch antenna with a woodpile EBG (b)

In this section, a woodpile structure is applied as a straight and curved layer of rods to the microstrip patch antenna and the results have been analyzed using HFSS software. The structure of these antennas is shown in Fig. 8. The obtained results are shown in Fig. 9 and Fig. 10. As demonstrated, the increase in the gain was only about $0.1 \mathrm{~dB}$ and the $S$ parameters have 
been improved (Fig. 10). Therefore, the gain of one-layer woodpile EBG structures is less than the gain of twolayer structures, but one-layer woodpile EBG structures are easier to build.



a

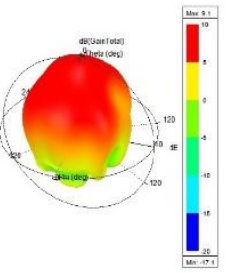

$\mathrm{b}$

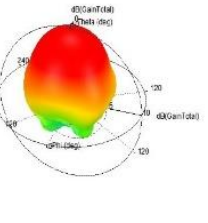

$\mathrm{c}$
Fig. 7 - The 3D polar plot: microstrip tree-patch antenna (a); microstrip tree-patch antenna with a mushroom-like EBG structure (b); microstrip tree-patch antenna with a woodpile EBG structure (c)



a



$\mathrm{b}$
Fig. 8 - The structure of an antenna created by HFSS software. Microstrip patch antenna with one curved layer of a woodpile structure (a), microstrip antenna with one straight layer of a woodpile structure (b)

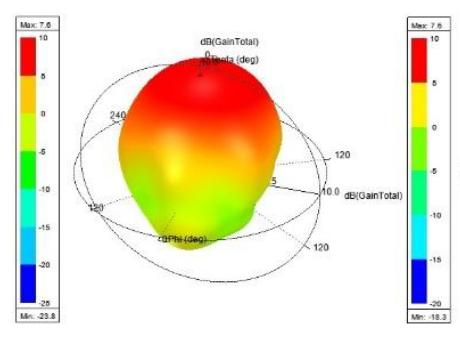

a

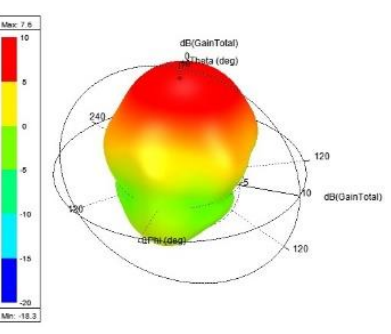

$\mathrm{b}$
Fig. 9- The obtained results from simulation. Microstrip patch antenna with one curved layer of a woodpile structure (a), microstrip antenna with one straight layer of a woodpile structure (b)

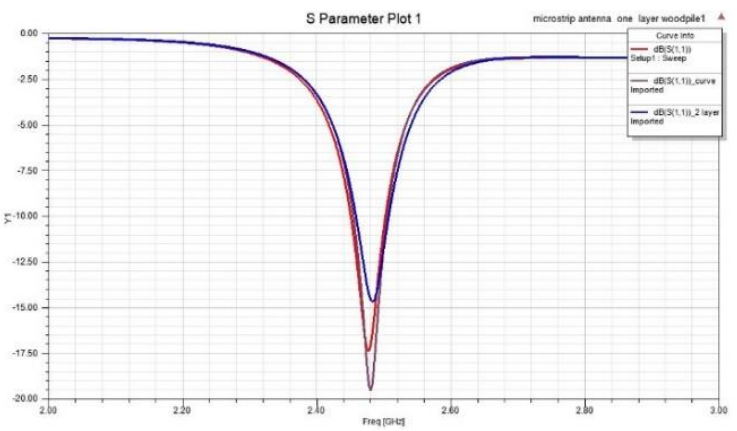

Fig. 10 - $S$ parameters of a microstrip patch antenna, microstrip antenna with one curved layer of a woodpile structure, microstrip antenna with one straight layer of a woodpile structure
As demonstrated in Fig. 10, the $S$ parameters are reasonably acceptable for determining the bandwidth. Also as it is shown, the bandwidth of a curved woodpile is a little more than the others.

\section{ANTENNA ARRAY}

A double element microstrip patch antenna with different types of mushroom-like EBG has been analyzed by HFSS software [20]. The performance of the array changes if EBG parameters are changed which is shown in the results (Fig. 12 and Fig. 13). The shape of the proposed structures is given in Fig. 11.

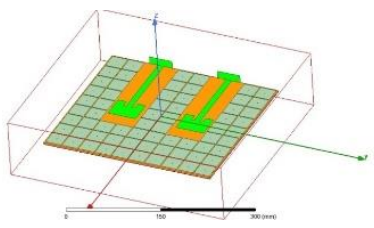

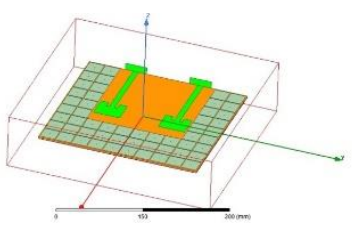

$\mathrm{b}$
Fig. 11 - The structures of a proposed model. Microstrip patch antenna array with internal EBG elements (a), microstrip patch antenna array without internal EBG elements (b)

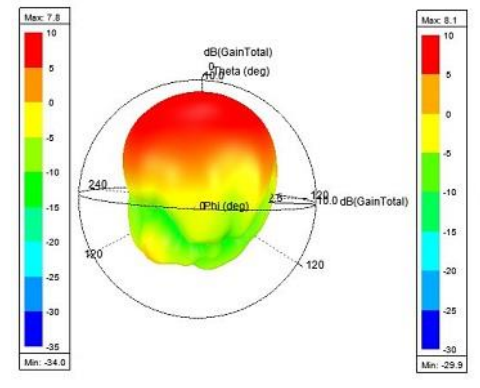

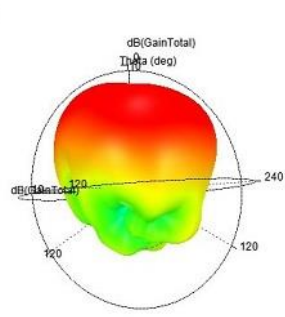

$\mathrm{b}$
Fig. 12 - Gain plot of a microstrip patch antenna array with internal EBG elements (a), gain plot of a microstrip patch antenna array without internal EBG elements (b)

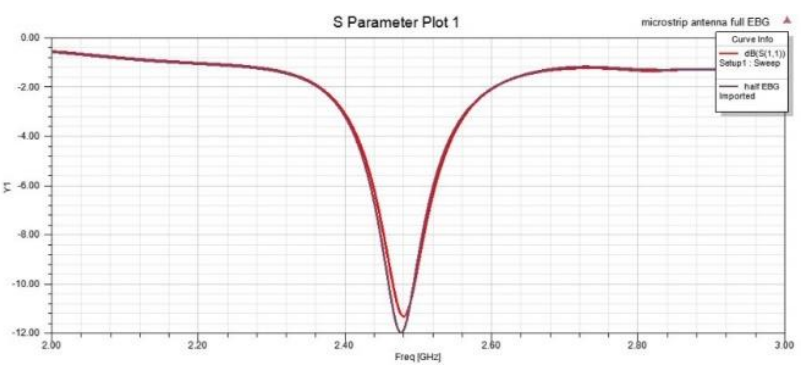

Fig. 13-S parameters of a microstrip patch antenna array with internal EBG elements

\section{CONCLUSIONS}

Different types of metamaterial structures have been studied for achieving gain enhancement in telemedicine applications which are created and simulated by HFSS software. The results show that the offered metamaterial structures have high gain and reasonable $S$ parameters. In the proposed antennas with metamaterial structures, the antenna with a woodpile EBG has maximum gain and reasonable $S$ parameters. We also added two metamaterial structures to the previously 
Table 4 - Comparison between gains of proposed antennas

\begin{tabular}{|l|l|}
\hline \multicolumn{1}{|c|}{ Antenna } & Gain \\
\hline Typical microstrip patch & $7.5 \mathrm{~dB}$ \\
\hline Mushroom-like EBG & $8.2 \mathrm{~dB}$ \\
\hline Woodpile one-layer EBG & $7.6 \mathrm{~dB}$ \\
\hline Woodpile two-layer EBG & $9.5 \mathrm{~dB}$ \\
\hline
\end{tabular}

\begin{tabular}{|l|c|}
\hline \multicolumn{1}{|c|}{ Antenna } & Gain \\
\hline Tree-antenna & $8.1 \mathrm{~dB}$ \\
\hline Tree-antenna with mushroom-like EBG & $8.9 \mathrm{~dB}$ \\
\hline Tree-antenna with woodpile EBG & $9.1 \mathrm{~dB}$ \\
\hline
\end{tabular}

\section{REFERENCES}

1. B. Fong, A.C. Fong, C.K. Li, Telemedicine technologies. Information Technologies in Medicine and Telehealth (2011).

2. H. Shirzadfar, F. Lotfi, Int. J. Biosens. Bioelectron. 3 No 4, 00070 (2017).

3. H. Shirzadfar, P. Shirvani, J Bioanal. Biomed. 8 No 5, 1000e145 (2016)

4. J. Craig, V. Petterson, J. Telemed Telecare 11 No 1, 3 (2005).

5. D. Bloom, R. Hunter, M.E. Williams, Telemed. Today 4 No 3, 35 (1996).

6. R. Wootton, J. Craig, Introduction to telemedicine (Kindel ed.: 2006).

7. B. Cermack, British J. Anaesthesia 97 No 1, 107 (2006)

8. A.D. Ausseresses, J. Med. Syst. 19 No 2, 143 (1995).

9. C.S. Pattichis, E. Kyriacou, S. Voskarides, M.S. Pattichis, R. Istepanian, C.N. Schizas, IEEE Antennas Propag. Mag. 44 No 2, 143 (2002).

10. J.R. James, P.S. Hall, Handbook of microstrip antennas. IET, 856 (1989).

\section{Підвищення коефіціента посилення мікрополоскової патч-антени і решітчастої антени 3 \\ використанням різних структур метаматеріалів для додатків телемедицини}

\author{
Parisa Shirvani ${ }^{1}$, Hamidreza Shirzadfar ${ }^{2}$ \\ ${ }^{1}$ Sepahan Institute of Higher Education, Sepahan-shahr, Isfahan, Iran \\ 2 Department of Electrical and Biomedical Engineering, Faculty of Engineering and Technology, Shahid Ashrafi \\ Isfahani University, Isfahan, Iran
}

11. R. Garg, P. Bartia, I. Bahl, A. Ittipiboon, Microstrip Antenna

S. Daniel, The Analysis and Design of Microstrip Antennas

Eneta, A Alù, R.W. Ziolkowski, A. Erentok, Phys. Eng.

R.O. Ouedraogo, E.J. Rothwell, A.R. Diaz, K. Fuchi, A. Temme, 5. X. Xu, J. Wei, IET Microwaves, Antennas P. 12 No 7, 1216 (2018).

17. A.R. Weily, L. Horvath, K.P. Esselle, B.C. Sanders, T.S. Bird, IEEE Trans. Antennas Propag. 53 No 1, 216 (2005).

P. Kamphikul, P. Krachodnok, R. Wongsan, Thailand-Japan

P. Shirvani, H. Shirzadfar, J. Nano- Electron. Phys. 8 No 3 , 03028 (2016)

20. O.M. Haraz, A. Elboushi, S.A. Alshebeili, A.R. Sebak, IEEE Access 2, 909 (2014).

Телемедицина - це форма віддаленої медичної практики з використанням інформаційних і комунікаційних технологій, яка сприяе дистанщійному посередництву між паціентом і медичним персоналом. У сільських або віддалених районах, де багато спеціалізованих медичних послуг, що необхідні спільноті, є недоступними, телемедицина може бути життездатною і надійною альтернативою для полегшення доступу до цих послуг, оскільки використання телемедичних технологій веде до більш високого рівня медичного обслуговування і лікування. Оскільки в телемедичних системах антени відіграють важливу роль, ми приділяемо особливу увагу оптимальній конструкції використовуваних антен для досягнення краших результатів. Роль антени полягае в перетворенні електричної енергії сигналу в електромагнітну енергію або, навпаки, в перетворенні електромагнітної енергії в електричну. Передавальна антена - це пристрій, який передає енергію між випромінювачем і вільним простором, де ця енергія буде поширюватися. Швидкий розвиток систем бездротового зв'язку привів до численних поліпшень в телекомунікаційних антенах і системах для задоволення потреб додатків телемедицини. Мікрополоскова патч-антена - це планарна антена, яка привернула багато уваги завдяки своїй плоскій геометрії. Ці типи антен дуже популярні серед дизайнерів і використовуються в багатьох додатках. У статті представлена вдосконалена патч-антена і решітчаста антенна з мікрополоскової лінією живлення з використанням трьох видів структур з метаматеріалів (МТM), які можуть бути дуже корисними в системах телемедицини. Метаматеріал - це штучний композитний матеріал з неприродними електромагнітними властивостями. Для отримання антени з гарними характеристиками розглядаються і аналізуються різні конструкції. Запропоновані структури збільшують коефіціент посилення антен, що використовуються в системах телемедицини. Обговорювалися і аналізувалися структури з грибоподібною електромагнітною забороненою зоною (EBG), одношаровою і двошаровою штабельною EBG прямої і вигнутої форм. Робоча частота для додатків телемедицини складає 2,45 ГГц. Процес моделювання було виконано за допомогою програмного забезпечення High Frequency Structure Simulator (HFSS), і результати порівнюються.

Ключові слова: Телемедицина, HFSS, Патч-антена, Метаматеріал, EBG, Штабель, Грибоподібний, Решітчаста антена. 